\title{
Application of Heated Water to Reduce Populations of Brettano- myces bruxellensis Present in Oak Barrel Staves
}

\author{
C.G. Edwards*, Z.M. Cartwright \\ School of Food Science, Washington State University, Pullman, WA, USA 99164-6376
}

Submitted for publication: June 2018

Accepted for publication: October 2018

Key words: Brettanomyces bruxellensis, oak staves, heated water, spoilage

\begin{abstract}
New $16 \mathrm{~L}$ and three-year-old commercial $225 \mathrm{~L}$ barrels representing French and American oaks of different toasting levels, contaminated with Brettanomyces bruxellensis, were obtained. Center sections of individual staves were sawn into $3 \times 3 \mathrm{~cm}$ cubes and submerged $2 \mathrm{~mm}$ into heated water at $50^{\circ} \mathrm{C}, 6^{\circ} \mathrm{C}, 70^{\circ} \mathrm{C}$, or $^{\circ}$ $8^{\circ} \mathrm{C}$. Following heat treatment, cross sections and/or shavings were collected and transferred into a yeast recovery medium for incubation for $\geq \mathbf{6 0}$ days. Culturable cells were not recovered from cubes heated in water at $70^{\circ} \mathrm{C}$ for 20 minutes, or $80^{\circ} \mathrm{C}$ for 15 minutes, when the yeast was present in oak at depths of $\leq 4$ $\mathrm{mm}$. However, longer heating times $\left(70^{\circ} \mathrm{C}\right.$ for $30 \mathrm{~min}$ or $80^{\circ} \mathrm{C}$ for $\left.20 \mathrm{~min}\right)$ were required if $\mathrm{B}$. bruxellensis was present at depths of 5 to $9 \mathrm{~mm}$ within cubes made from staves. Based on these results, heating water to at least $70^{\circ} \mathrm{C}$ for a minimum of 30 minutes is recommended to reduce risk of wine spoilage by barrels contaminated with $B$. bruxellensis.
\end{abstract}

\section{INTRODUCTION}

Contaminated oak barrels are well-known to contribute to the spread of the yeast Brettanomyces bruxellensis within wineries (Chatonnet et al., 1992; Fugelsang \& Edwards 2007). To minimise the potential for spoilage, various sanitation methods for barrels have been evaluated, including microwaves (González-Arenzana et al., 2013), ozone (Guzzon et al., 2011; 2013) and high power ultrasonic waves (Yap et al., 2008; Schmid et al., 2011). However, culturable yeasts have been recovered from $8 \mathrm{~mm}$ deep within staves (Malfeito-Ferreira et al., 2004; Barata et al., 2013; Cartwright et al., 2018), a depth beyond penetration by these methods.

As such, alternative approaches to these methods, such as using heat (e.g. steam or hot water) have been more widely adopted by the wine industry. In fact, $B$. bruxellensis can be inactivated even at mildly elevated temperatures, beginning at approximately $50^{\circ} \mathrm{C}$ (Couto et al., 2005; Fabrizio et al., 2015). More recently, Cartwright et al. (2018) reported that steaming staves for 9 to 12 minutes eliminated yeast populations, depending on oak species and toasting level. Even though evidence does not currently exist, application of commercial steaming units could result in uneven heating or "cold spots" within barrels, thereby not completely inactivating viable cells.

Compared to steam, filling and/or submersion with heated water may, in fact, more reliably reduce microbial populations by attaining uniform temperatures throughout the barrel. Of the few studies available, Fabrizio et al. (2015) noted that immersing barrels for extended periods of time in heated water significantly reduced resident $B$. bruxellensis populations. However, this study analysed rinse water from barrels to evaluate efficacy of heated water treatments. Even though $B$. bruxellensis can deeply penetrate staves, there are areas where cells will not be removed through rinsing. In fact, the yeast can survive application of steam to the surface of wood if present at depths of 5 to $9 \mathrm{~mm}$ (Cartwright et al., 2018).

The objective of this research was to determine the impact of heated water on the recovery of $B$. bruxellensis from oak staves.

\section{MATERIAL AND METHODS \\ Cultures and barrels}

Strains of $B$. bruxellensis I1 a and E1 (Jensen et al., 2009), media used for starter culture preparation and recovery (WRM and EBB), as well as sources of barrels were described by Cartwright et al. (2018). Briefly, a commercially prepared Cabernet Sauvignon wine ( $\mathrm{pH} 3.39,6.09 \mathrm{~g} / \mathrm{L}$ titratable acidity as tartaric acid, $13.5 \% \mathrm{v} / \mathrm{v}$ alcohol, and $18 \mathrm{mg} / \mathrm{L}$ free $\mathrm{SO}_{2}$ ) was added to $16 \mathrm{~L}$ new American or French oak barrels with light or heavy toast levels prior to inoculation, with B. bruxellensis strain I1a or E1, with an incubation period of several weeks. Additionally, four $225 \mathrm{~L}$ three-year-old commercial barrels infected with an unidentified B. bruxellensis strain(s) were obtained from a regional winery.

\footnotetext{
*Corresponding author: E-mail address: edwardsc@wsu.edu

Acknowledgments: The authors gratefully acknowledge the Washington State Grape and Wine Research Program, the Ivory Tower Scholarship Fund, regional and national wineries and the School of Food Science at Washington State University for financial and material support
} 


\section{Heated water or wine treatments}

Center portions of side staves from disassembled barrels were sawn into $3 \times 3 \mathrm{~cm}$ cubes. A stainless steel plate $(0.3 \mathrm{~cm} \mathrm{x}$ $28 \mathrm{~cm} \times 43 \mathrm{~cm}$ ), fitted with bottomless circular chambers (4 cm diameter $\times 2 \mathrm{~cm}$ depth), was manufactured locally and used to hold 24 individual cubes immersed approximately $2 \mathrm{~mm}$ into heated water. The loaded plate was placed into $4 \mathrm{~L}$ of circulating distilled water held at $50^{\circ} \mathrm{C}, 60^{\circ} \mathrm{C}, 70^{\circ} \mathrm{C}$, or $80^{\circ} \mathrm{C}$. During heat application, a steel cover was overlaid to prevent movement of the stave cubes. Selected cubes were fitted with thermocouples (Omega Engineering, Stamford, $\mathrm{CT}$ ) installed into $1.0 \mathrm{~mm}$ diameter holes and were centrally located at varying depths $1.5 \mathrm{~cm}$ into each block. Each experiment was conducted twice, with three cubes removed at each designated time and the water changed each time. After heating, cubes were sawn into $4 \mathrm{~mm}$ thick horizontal crosssections and individually placed into sterile $100 \mathrm{~mL}$ sampling bags (Nasco, Salida, CA). Sterilized wine recovery medium (WRM, $40 \mathrm{~mL}$ ) was added to all bags, which were then incubated at $27^{\circ} \mathrm{C}$ for at least 60 days.

Decimal reduction times at a given temperature to kill $1 \log$ of yeast $\left(\mathrm{D}_{\mathrm{T}}\right)$ were estimated by heating $3 \times 3$ cubes obtained from heavy toasted $16 \mathrm{~L}$ barrels (French oak) in a water bath. The heated cubes were immediately placed in sterile bags and allowed to cool to room temperature for at least 24 hours. Wood shavings were then prepared using a sterilized $2.5 \mathrm{~cm}$ Forstner drill bit, which bored $2 \mathrm{~mm}$ holes in increments. The shavings were collected and transferred into $25 \mathrm{~mL}$ EBB medium, to incubation at $20^{\circ} \mathrm{C}$ with shaking (100 rpm) for 12 hours to remove cells from oak before determination of yeast culturability.

All equipment used (table and band-saws, Forstner drill bits, heating plate, etc.) were regularly sanitized using $70 \%$ $\mathrm{v} / \mathrm{v}$ ethanol

\section{Analyses}

Culturability was determined using both manual and spiral plate methods (Autoplate 4000 spiral plater, Spiral Biotech, Bethesda, MD), and Wallerstein Differential medium (Difco, Detroit, MI). After incubation at $27^{\circ} \mathrm{C}$ for six days, colonies were counted and tentatively identified based on physical appearance as well as cellular morphologies viewed with phasecontrast microscopy. Identification of randomly selected colonies (three per barrel) was later confirmed using genetic ITS sequencing (MIDI Labs, Newark, DE).

Chemical analyses $\left(\mathrm{pH}\right.$, titratable acidity and $\left.\mathrm{SO}_{2}\right)$ were performed by standardized methods (Edwards \& Watson, 2013); 4-ethylphenol (4-EP) and 4-ethylguaiacol (4-EG) by gas chromatography-mass spectroscopy (Jensen et al., 2009); ethanol using an ebulliometer (Alla, Chemillé, France).

Analysis of variance (ANOVA) and Tukey's HSD for mean separation was determined at $p \leq 0.05$ using XLSTAT software (Addinsoft, New York, NY).

\section{RESULTS AND DISCUSSION}

\section{Heating staves}

Increases in temperature of the $3 \times 3$ cubes at different layers during water heating depended primarily on stave depth, not on oak species or the toasting level. In fact, since American and French oak from $16 \mathrm{~L}$ barrels heated almost identically $(p \leq 0.05)$, data were pooled to further assess heating profiles within staves (Fig. 1). Typically, innermost surfaces directly in contact with water reached the treatment temperature within $\leq 5$ minutes, while furthermost surfaces $(\geq 20 \mathrm{~mm})$ remained below $30^{\circ} \mathrm{C}$, similar to the observations regarding $225 \mathrm{~L}$ barrels (data not shown). At $9.5 \mathrm{~mm}$, a stave depth slightly beyond where $B$. bruxellensis has been recovered (MalfeitoFerreira et al., 2004; Barata et al., 2013; Cartwright et al., 2018), heated treatments of $50^{\circ} \mathrm{C}$ (Fig. 1A) or $60^{\circ} \mathrm{C}$ (Fig. 1B)

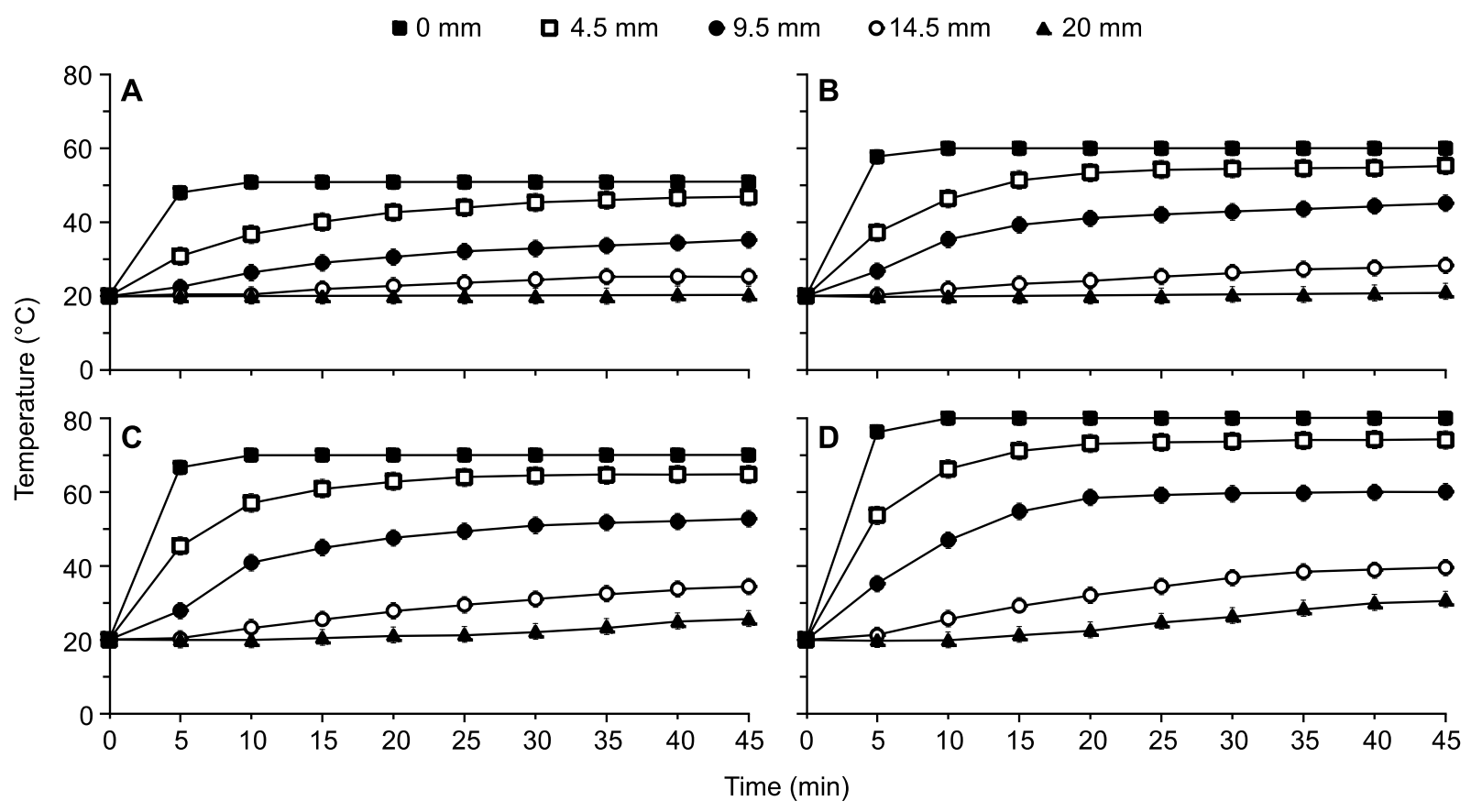

FIGURE 1

Heat penetration at different layers into French/American oak staves from $16 \mathrm{~L}$ barrels (pooled data), held at a depth of $2 \mathrm{~mm}$ in circulating water at $50^{\circ} \mathrm{C}(\mathrm{A}), 60^{\circ} \mathrm{C}(\mathrm{B}), 70^{\circ} \mathrm{C}(\mathrm{C})$, or $80^{\circ} \mathrm{C}(\mathrm{D})$. Data represent means \pm standard error $(\mathrm{n}=8)$. 
resulted in maximum temperatures of $35^{\circ}$ or $47^{\circ} \mathrm{C}$ after 45 minutes, respectively. However, shorter times of 25 minutes or 15 minutes were required at $70^{\circ}$ (Fig. 1C) or $80^{\circ} \mathrm{C}$ (Fig. 1D), respectively, in order to reach $\geq 50^{\circ} \mathrm{C}$. Cubes never attained $\geq 60^{\circ} \mathrm{C}$ at $9.5 \mathrm{~mm}$ depths within 45 minutes. Temperatures higher than those have been reported by Cartwright et al. (2018) for the same oak staves, but were heated by steam.

\section{Yeast recoveries from heated staves}

B. bruxellensis strain I1a was found in the $5 \mathrm{~mm}$ to $9 \mathrm{~mm}$ layer of heavy toasted $16 \mathrm{~L}$ barrels made from French oak, but not in the same layer within the light or heavy toasted American oak (Fig. 2 to 5). These analyses were in agreement with observations of $16 \mathrm{~L}$ barrels as reported by Cartwright et al. (2018), where the two types of oak had different permeabilities to B. bruxellensis, yet similar thermal conductivities.

In general, as the temperature of heated water increased, shorter treatment periods were required to eliminate culturable cells. Application of $50^{\circ} \mathrm{C}$ (Fig. 2) resulted in elimination of the yeast after 60 minutes from the $0 \mathrm{~mm}$ to $4 \mathrm{~mm}$ layer of American oak, but required 120 minutes for the French oak due to the presence of $B$. bruxellensis in the $5 \mathrm{~mm}$ to $9 \mathrm{~mm}$ layer. After 30 minutes of heating American oak , 15 days of incubation in WRM was required to detect Brettanomyces populations. An incubation period of 15 days implied that the populations were low but still culturable after water heating. In comparison, 30 days of incubation was needed to observe viable cells from staves treated for 60 minutes for French oak. For French oak treated with water at $60^{\circ} \mathrm{C}$ (Fig. 3), $70^{\circ} \mathrm{C}$ (Fig. 4) or $80^{\circ} \mathrm{C}$ (Fig. 5), the times needed to eradicate the yeast decreased from 45, 30, to 20 minutes, respectively. At these same temperatures, yeast recovery was not observed from the American oak after 30, 20 , or 15 minutes, respectively. While these data were based on heavy toasted staves, similar trends were observed for the light toasted French and American oak (data not shown).

$\mathrm{D}_{\mathrm{T}}$ values for B. bruxellensis strains I1a (Fig. 6A) or E1 (Fig. 6B) were determined using cubes prepared from $16 \mathrm{~L}$ heavy toasted French oak staves. From initial populations of approximately $6 \times 10^{3} \mathrm{cfu} / \mathrm{g}$, culturabilities were monitored over time within the $0 \mathrm{~mm}$ to $2 \mathrm{~mm}$ layer immersed in the heated water. Based on slopes of best fit lines $\left(r^{2} \geq 0.88\right)$, $\mathrm{D}_{50^{\circ} \mathrm{C}}, \mathrm{D}_{60^{\circ} \mathrm{C}}, \mathrm{D}_{70^{\circ} \mathrm{C}}$ and $\mathrm{D}_{80^{\circ} \mathrm{C}}$ were estimated to be $223 \mathrm{sec}, 50$ sec, $20 \mathrm{sec}$, and $11 \mathrm{sec}$ for strain I1a (Fig. 6A), values similar to that of strain E1 (Fig. 6B).

To date, the limited studies available regarding thermal inactivation of $B$. bruxellensis relied upon liquid cultures, not on oak staves as described in the current research. Couto et al. (2005) noted $\mathrm{D}_{50^{\circ} \mathrm{C}}$ to be 204 to $228 \mathrm{sec}$ for strain PYCC 4801, in agreement with strains I1a and E1 (Fig. 6). Using liquid cultures, Couto et al. (2005) observed $\mathrm{D}_{55^{\circ} \mathrm{C}}$ of a single strain of $B$. bruxellensis to vary between 18 to $24 \mathrm{sec}$ whereas Fabrizio et al. (2015) found $\mathrm{D}_{60^{\circ} \mathrm{C}}$ values to range from 19.5 to $20.7 \mathrm{sec}$. Furthermore, Fabrizio et al. (2015) noted that three strains behaved similarly, while the fourth exhibited a slightly greater heat resistance. In general, the $\mathrm{D}_{\mathrm{T}}$ values reported by Couto et al. (2005) and Fabrizio et al. (2015) at temperatures $>50^{\circ} \mathrm{C}$ were lower than those obtained with staves, possibly due to matrix effects, as oak exhibits a lower thermal conductivity (Lagüela et al., 2015) compared to

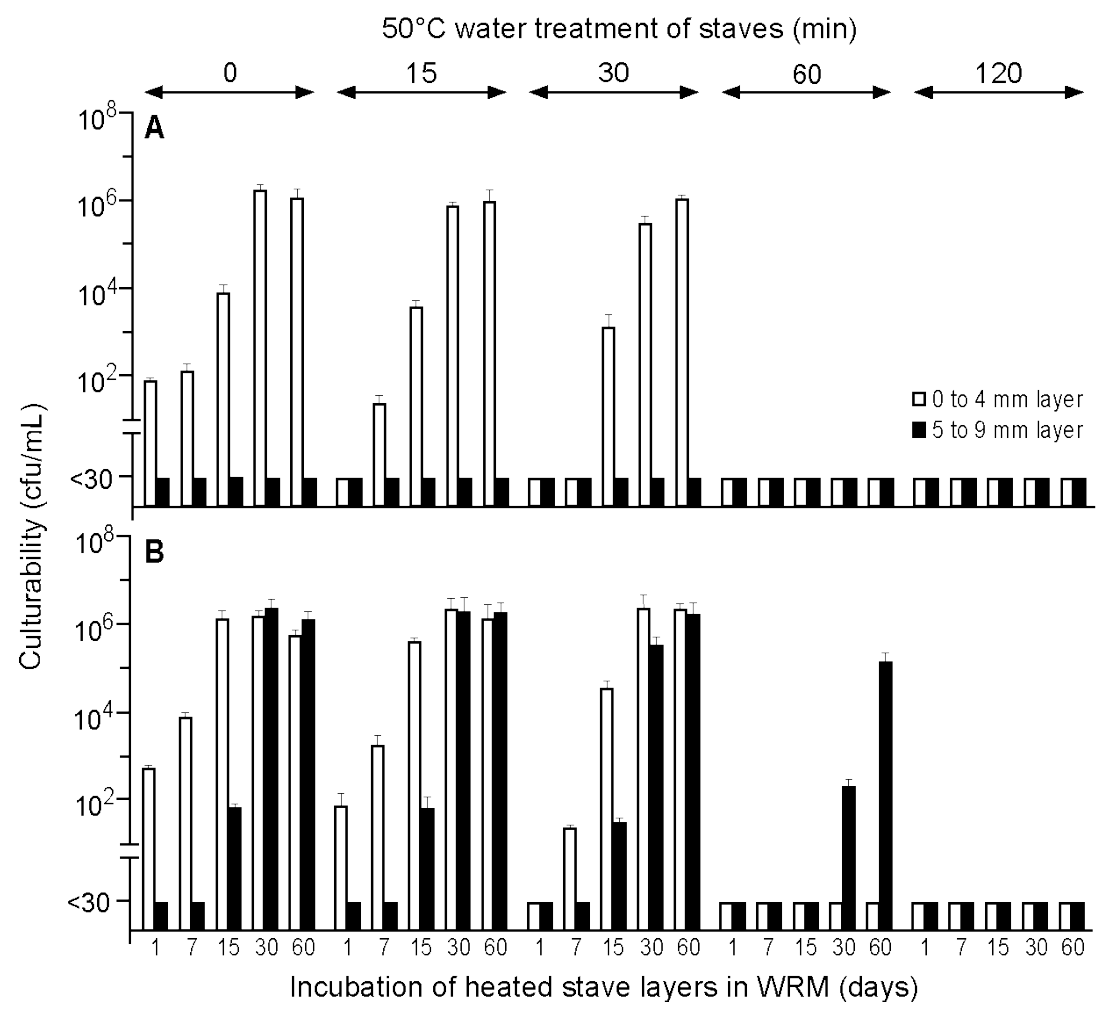

FIGURE 2

Culturabilities of B. bruxellensis strain I1a recovered from heavy toasted American (A) or French (B) 16 L oak barrels following $50^{\circ} \mathrm{C}$ water treatments. Data represent means \pm standard error $(\mathrm{n}=6)$. 


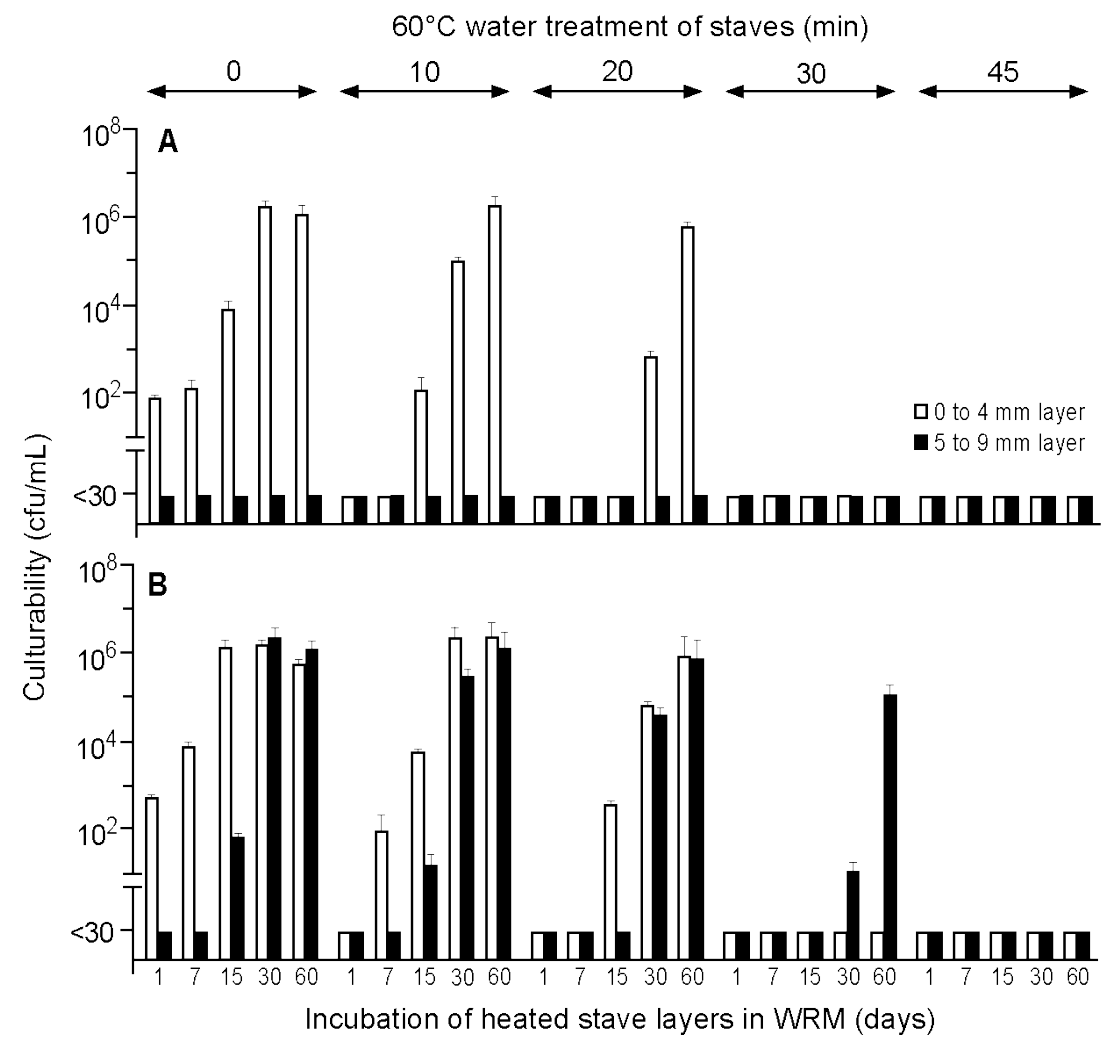

FIGURE 3

Culturabilities of B. bruxellensis strain I1 a recovered from heavy toasted American (A) or French (B) 16 L oak barrels following $60^{\circ} \mathrm{C}$ water treatments. Data represent means \pm standard error $(n=6)$.

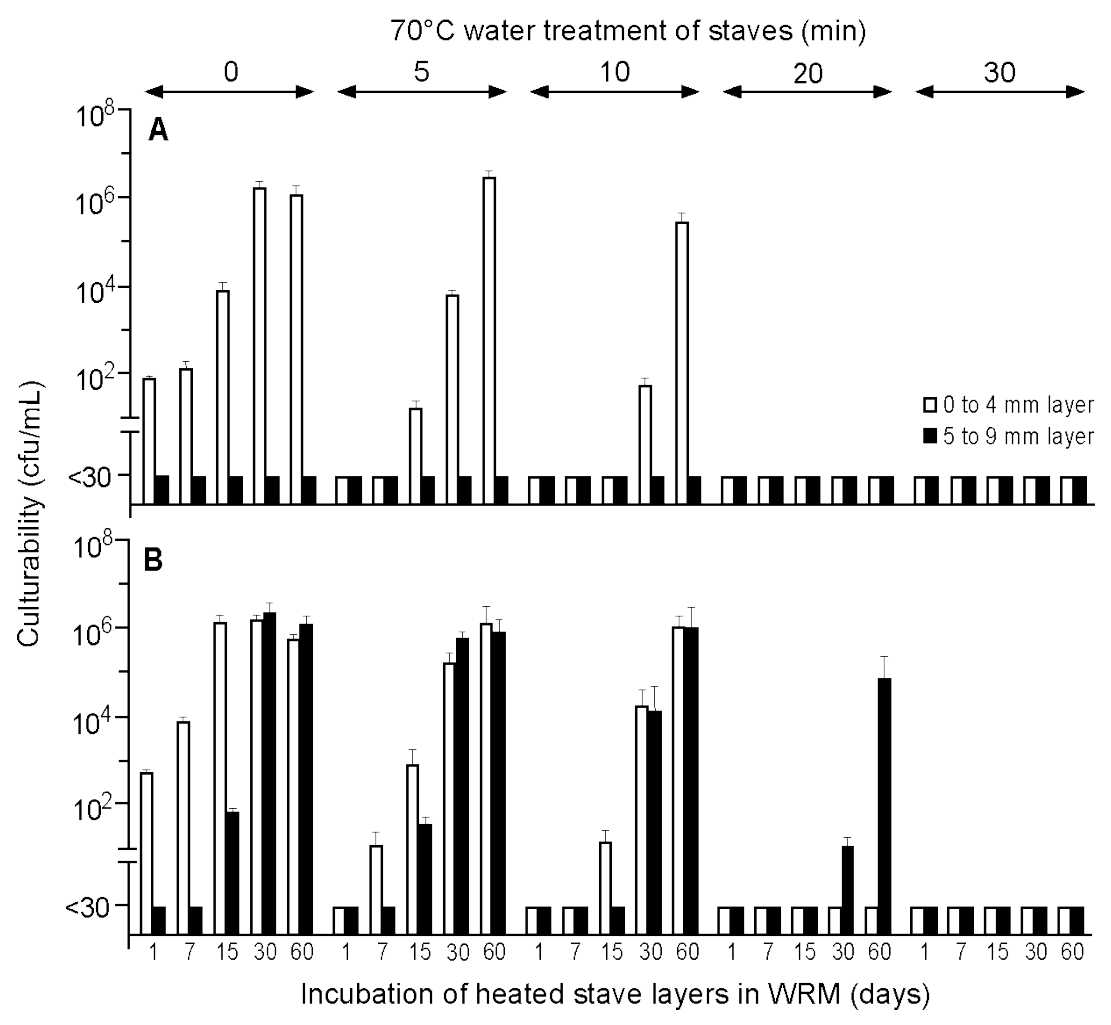

FIGURE 4

Culturabilities of B. bruxellensis strain I1 a recovered from heavy toasted American (A) or French (B) 16 L oak barrels following $70^{\circ} \mathrm{C}$ water treatments. Data represent means \pm standard error $(n=6)$. 


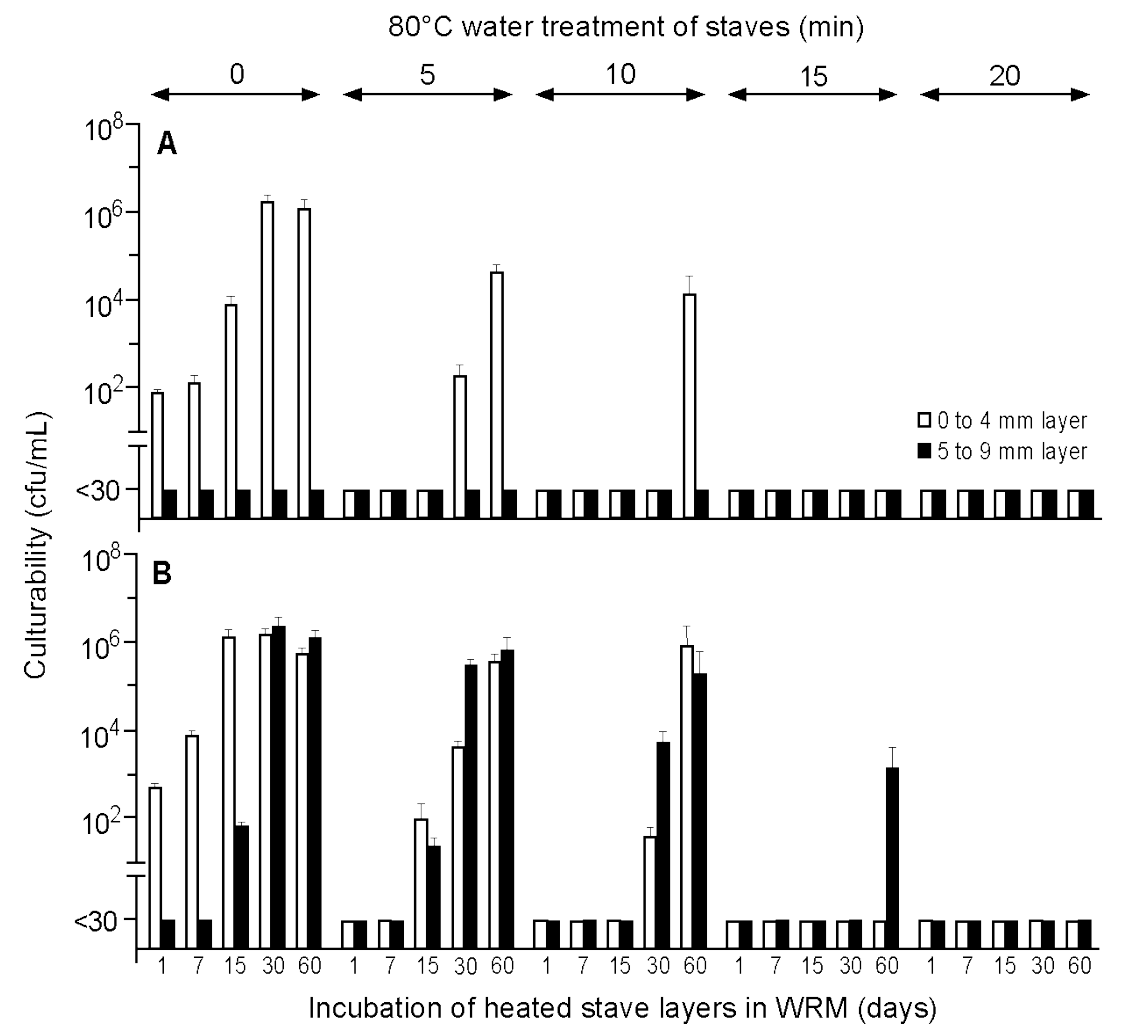

FIGURE 5

Culturabilities of B. bruxellensis strain I1 a recovered from heavy toasted American (A) or French (B) 16 L oak barrels following $80^{\circ} \mathrm{C}$ water treatments. Data represent means \pm standard error $(n=6)$.

heating liquid cultures. In addition, heat resistance may vary between different strains of $B$. bruxellensis as suggested by Fabrizio et al. (2015).

Given differences in dimensions (i.e., stave thickness) and age compared to the $16 \mathrm{~L}$ barrels, cubes were sawn from $225 \mathrm{~L}$ barrel staves and exposed to heated water using previously described protocols (Fig. 7 to 10). Unlike the $16 \mathrm{~L}$ barrels, culturable cells were recovered from $5 \mathrm{~mm}$ to $9 \mathrm{~mm}$ layers from American oak barrels, most likely because these had been commercially used for three years, allowing slow but deeper penetration of the yeast (Cartwright et al., 2018). Like the $16 \mathrm{~L}$ barrels, however, yeast recovery was largely affected by water temperature and time of heat exposure. For example, culturable cells were recovered from the $5 \mathrm{~mm}$ to $9 \mathrm{~mm}$ layer, but not the 0 to $4 \mathrm{~mm}$ for both American and French oaks after 60 minutes of heating at $50^{\circ} \mathrm{C}$ (Fig. 7). Elimination of $B$. bruxellensis from these staves was noted after 120 minutes of heating. As the temperature of water was increased, the heating time, which resulted in no recoverable cells from the $5 \mathrm{~mm}$ to $9 \mathrm{~mm}$ stave layer, also decreased from 45 minutes $\left(60^{\circ} \mathrm{C}\right.$; Fig. 8$)$ to 30 minutes $\left(70^{\circ} \mathrm{C}\right.$; Fig. 9), and then to 20 minutes $\left(80^{\circ} \mathrm{C}\right.$; Fig. 10). Overall, inactivation of the unidentified strain(s) that was present in the $225 \mathrm{~L}$ barrels followed the same trends as those observed in the $16 \mathrm{~L}$ barrels infected with another strain of $B$. bruxellensis.

Even though some studies concluded that heat treatments did not adequately remove $B$. bruxellensis from staves, others disagreed. For instance, Barata et al. (2013) concluded that steam treatments of 10 minutes for French

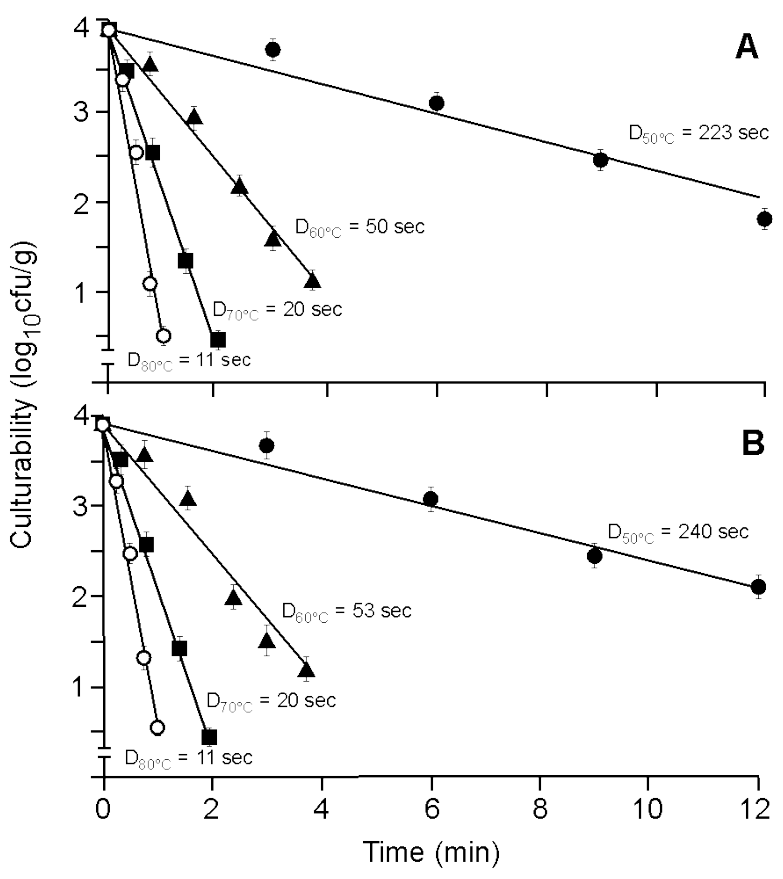

FIGURE 6

D-values for B. bruxellensis strain I1a (A) or E1 (B) recovered from the first $2 \mathrm{~mm}$ depths of heavy toasted $16 \mathrm{~L}$ French oak barrels following heated water treatments. Data represent means \pm standard error $(n=3)$. 


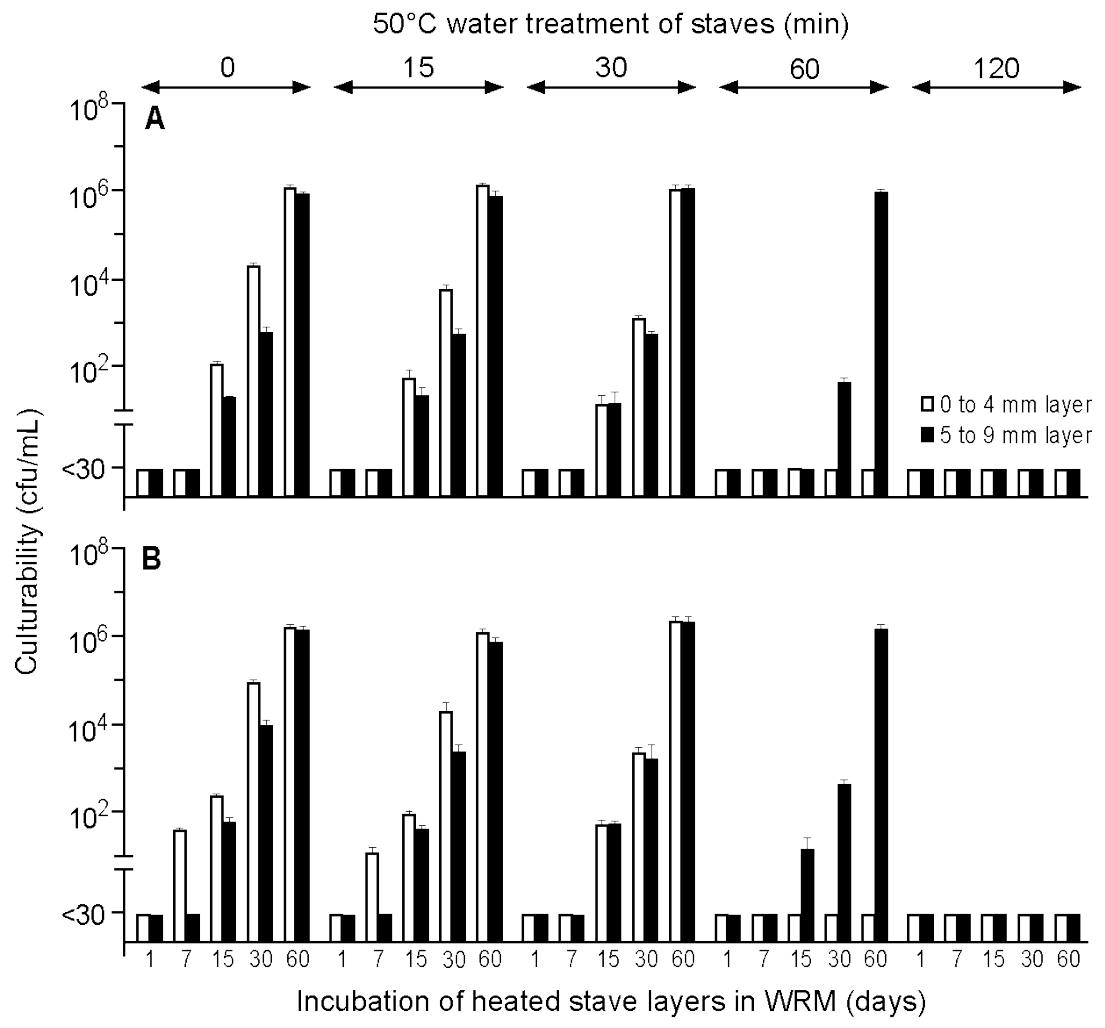

FIGURE 7

Culturabilities of an unidentified strain(s) of B. bruxellensis recovered from medium-heavy toasted American (A) or mediumlight toasted French (B) $225 \mathrm{~L}$ oak barrels following treatment with $50^{\circ} \mathrm{C}$ water. Data represent means \pm standard error $(\mathrm{n}=6$ ).

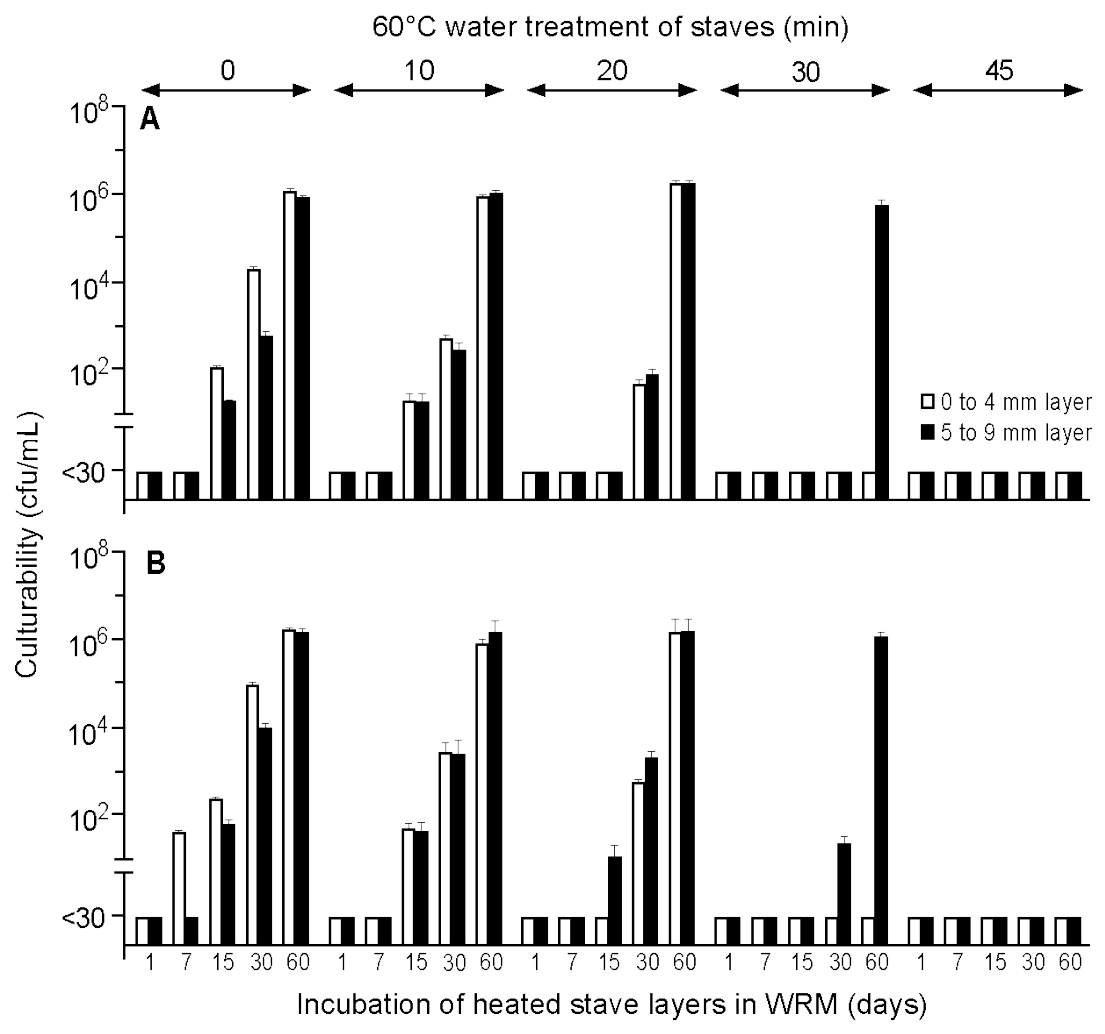

FIGURE 8

Culturabilities of an unidentified strain(s) of B. bruxellensis recovered from medium-heavy toasted American (A) or mediumlight toasted French (B) $225 \mathrm{~L}$ oak barrels following treatment with $60^{\circ} \mathrm{C}$ water. Data represent means \pm standard error $(\mathrm{n}=6)$. 


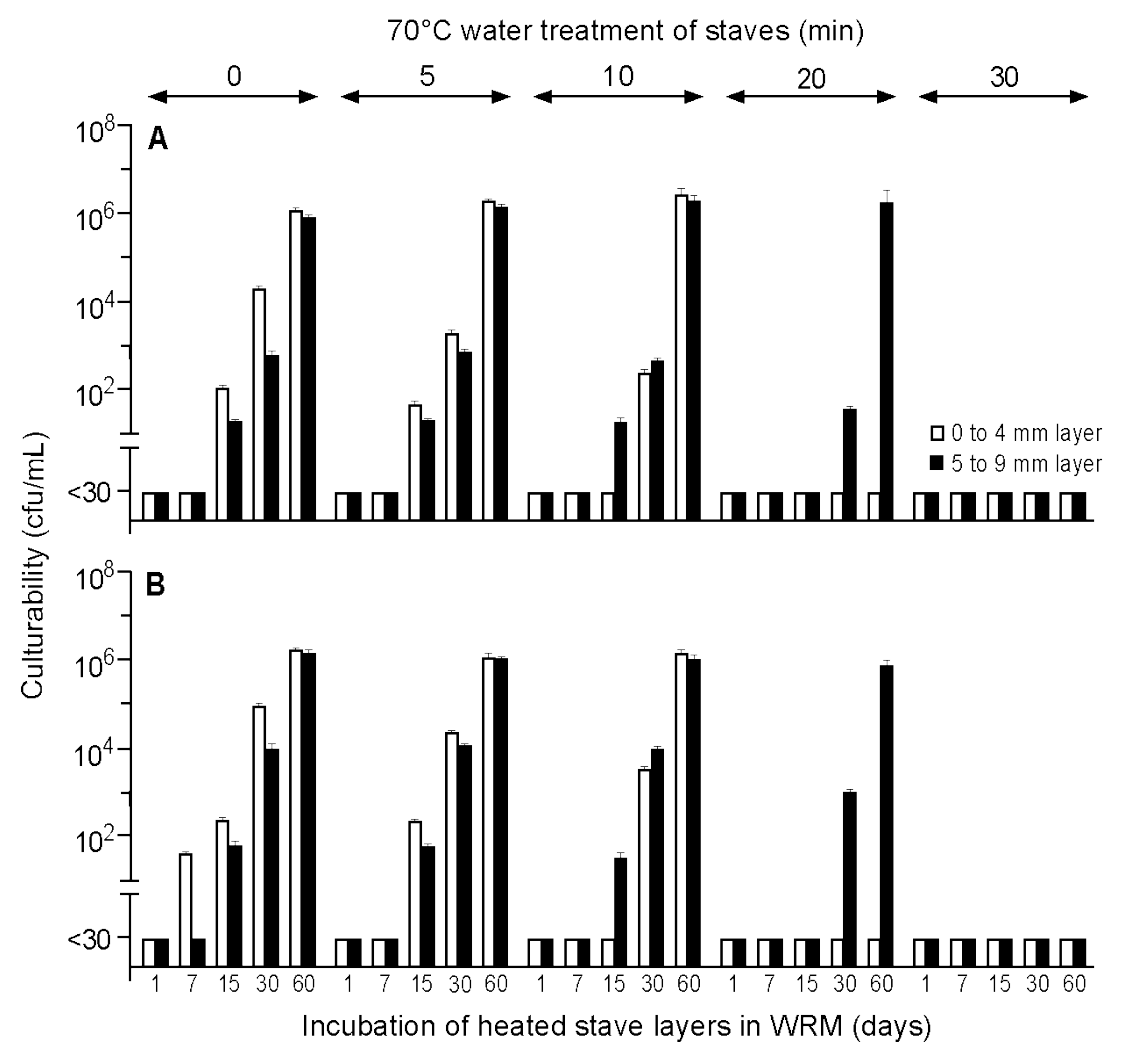

FIGURE 9

Culturabilities of an unidentified strain(s) of B. bruxellensis recovered from medium-heavy toasted American (A) or mediumlight toasted French (B) $225 \mathrm{~L}$ oak barrels following treatments with $70^{\circ} \mathrm{C}$ water. Data represent means \pm standard error $(\mathrm{n}=6)$.

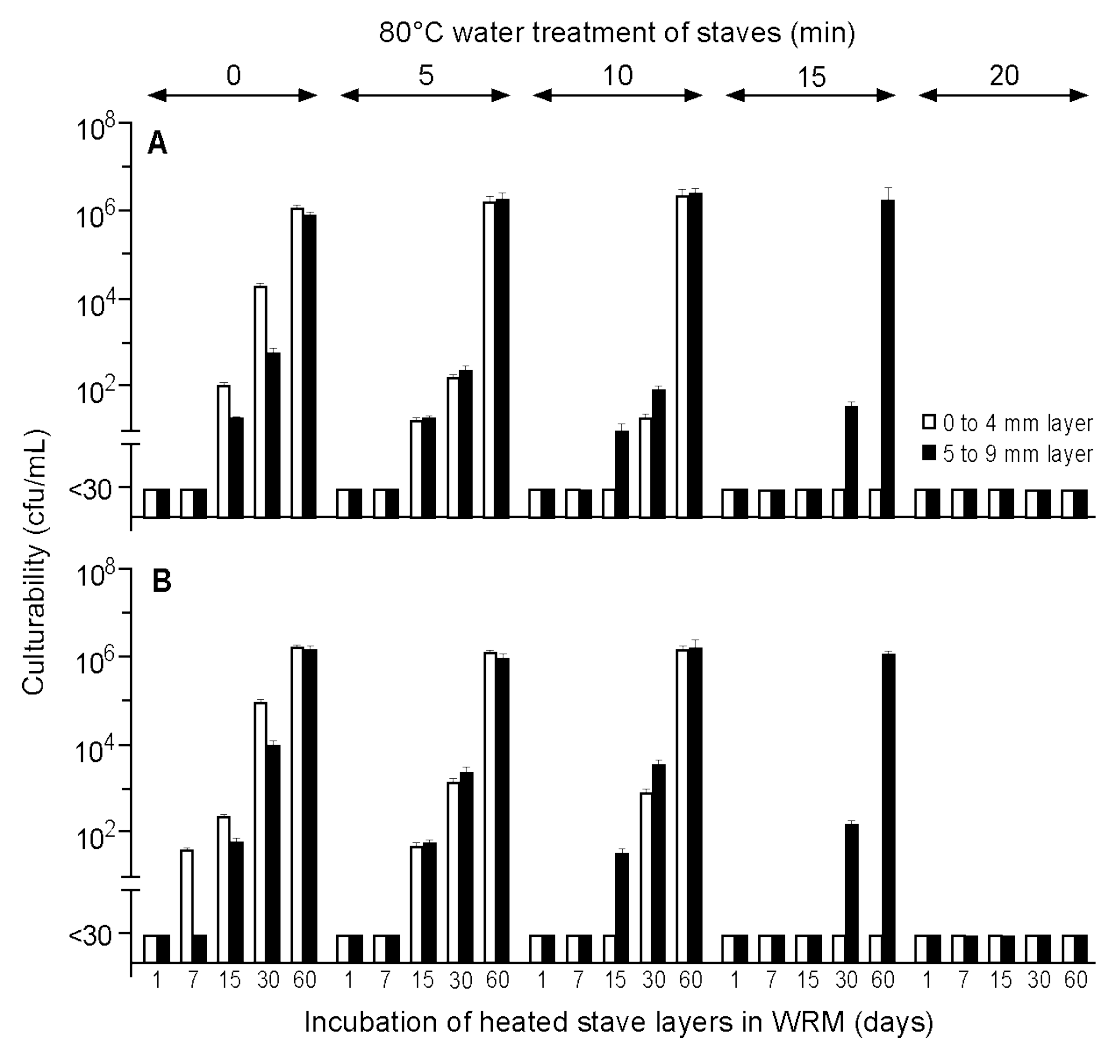

FIGURE 10

Culturabilities of an unidentified strain(s) of B. bruxellensis recovered from medium-heavy toasted American (A) or mediumlight toasted French (B) $225 \mathrm{~L}$ oak barrels following treatments with $80^{\circ} \mathrm{C}$ water. Data represent means \pm standard error $(\mathrm{n}=6)$. 
oak were not effective, since the yeast could still be cultured from staves. However, this steam treatment may have been too short in time, as Cartwright et al. (2018) noted that 12 minutes were needed to eliminate viable cells up to an $8 \mathrm{~mm}$ depth in contaminated French oak barrels. Although hot water rinsing $\left(60^{\circ} \mathrm{C}\right)$ had limited impacts on oak flavour extraction, Schmid et al. (2011) concluded that this approach would not adequately sanitize barrels due to the underlying porous nature of oak. Rather, soaking barrels in hot water for extended periods of time appear to be effective against B. bruxellensis. Even though Fabrizio et al. (2015) reported $7-\log$ reductions in $B$. bruxellensis populations present in staves up to $8 \mathrm{~mm}$ using $60^{\circ} \mathrm{C}$ water for 19 minutes, the current study found that higher temperatures and longer treatment times were required to prevent yeast recovery.

\section{Volatile phenol production}

Upon incubation of stave layers or shavings in WRM, recovered B. bruxellensis continued to produce 4-EP and 4-EG (data not shown). Based on analysis of staves from $16 \mathrm{~L}$ barrels, concentrations surpassed $2000 \mu \mathrm{g} / \mathrm{L} 4-\mathrm{EP}$ and $300 \mu \mathrm{g} / \mathrm{L}$ 4-EG for strains I1a and E1, where populations exceeded $10^{6}$ $\mathrm{cfu} / \mathrm{mL}$ after 60 days. The concentrations produced by these strains were similar to those reported by Oswald \& Edwards (2017) using a different wine. Even though similar populations were reached, the unidentified strain(s) originating from $225 \mathrm{~L}$ barrels produced lower concentrations of volatile phenols; $\leq 13004-E P$ and $180 \mu \mathrm{g} / \mathrm{L} 4-E G$. Neither 4-EP or 4-EG were detected in WRM, where populations remained below the limit of detection; $<30 \mathrm{cfu} / \mathrm{mL}$.

\section{CONCLUSIONS}

This study evaluated the efficacy of heated water and wine treatments towards the removal of $B$. bruxellensis from a wide range of infected barrels. Water heated to $70^{\circ} \mathrm{C}$ or $80^{\circ} \mathrm{C}$ eradicated the yeast if present at depths of $0 \mathrm{~mm}$ to $4 \mathrm{~mm}$ ( 20 or 15 minutes, respectively) or $5 \mathrm{~mm}$ to $9 \mathrm{~mm}$ (30 or $20 \mathrm{~min}$ utes, respectively), evidenced by a lack of culturable cells - even after incubation of stave cross-sections in a wine recovery medium for 60 days. Future research should focus on application of heated water on entire barrels, including any potential changes to the sensory impacts of treated barrels.

\section{LITERATURE CITED}

Barata, A., Laureano, P., D’Antuono, I., Martorell, P., Stender, H., Malfeito-Ferreira, M., Querol, A. \& Loureiro, V., 2013. Enumeration and identification of 4-ethylphenol producing yeasts recovered from the wood of wine ageing barriques after different sanitation treatments. J. Food Res. 2, 140-149.
Cartwright, Z.M., Glawe, D.A. \& Edwards, C.G., 2018. Reduction of Brettanomyces bruxellensis populations from oak barrel staves using steam. Am. J. Enol. Vitic. 69, 400-409.

Chatonnet, P., Dubourdieu, D., Boidron, J. \& Pons, M., 1992. The origin of ethylphenols in wines. J. Sci. Food Agric. 60, 165-178.

Couto, J.A., Neves, F., Campos, F. \& Hogg, T., 2005. Thermal inactivation of the wine spoilage yeasts Dekkera/Brettanomyces. Int. J. Food Microbiol. 104, 337-344.

Edwards, C.G. \& Watson, B.A., 2013. Basic microbiological and chemical analyses for wine. Washington State University Cooperative Extension EM047. Pullman, WA.

Fabrizio, V., Vigentini, I., Parisi, N., Picozzi, C., Compagno, C. \& Foschino, R., 2015. Heat inactivation of wine spoilage yeast Dekkera bruxellensis by hot water treatment. Lett. Appl. Microbiol. 61, 186-191.

Fugelsang, K.C. \& Edwards, C.G., 2007. Wine microbiology: Practical applications and procedures. Springer, New York.

González-Arenzana, L., Santamaría, P., López, R., Garijo, P., Gutiérrez, A.R., Garde-Cerdán, T. \& López-Alfaro, I., 2013. Microwave technology as a new tool to improve microbiological control of oak barrels: a preliminary study. Food Control. 30, 536-539.

Guzzon, R., Widmann, G., Malacarne, M., Nardin, T., Nicolini, G. \& Larcher, R., 2011. Survey of the yeast population inside wine barrels and the effects of certain techniques in preventing microbiological spoilage. Eur. Food Res. Technol. 233, 285-291.

Guzzon, R., Nardin, T., Micheletti, O., Nicolini, G. \& Larcher, R., 2013. Antimicrobial activity of ozone. Effectiveness against the main wine spoilage microorganisms and evaluation of impact on simple phenols in wine. Aust. J. Grape Wine. Res. 19, 180-188.

Jensen, S.L., Umiker, N.L., Arneborg, N. \& Edwards, C.G., 2009. Identification and characterization of Dekkera bruxellensis, Candida pararugosa, and Pichia guilliermondii isolated from commercial red wines. Food Microbiol. 26, 915-921.

Lagüela, S., Bison, P., Peron, F. \& Romagnoni, P., 2015. Thermal conductivity measurements on wood materials with transient plane source technique. Thermochim Acta. 600, 45-51.

Malfeito-Ferreira, M., Laureano, P., Barata, A., D’Antuono, I., Stender, H. \& Loureiro, V., 2004. Effect of different barrique sanitation procedures on yeasts isolated from the inner layers of wood. Am. J. Enol. Vitic. 55, 304A.

Oswald, T.A. \& Edwards, C.G., 2017. Interactions between storage temperature and ethanol that affect growth of Brettanomyces bruxellensis in Merlot wine. Am. J. Enol. Vitic. 68, 188-194.

Schmid, F., Grbin, P., Yap, A. \& Jiranek, V., 2011. Relative efficacy of high pressure hot water and high power ultrasonics for wine oak barrel sanitization. Am. J. Enol. Vitic. 62, 519-526.

Yap, A., Schmid, F., Jiranek, V., Grbin, P. \& Bates, D., 2008. Inactivation of Brettanomyces/Dekkera in wine barrels by high power ultrasound. Wine Ind. J. 23, 32-40. 